\title{
Physical activity during the COVID-19 pandemic: a survey with adults in Northern Brazil
}

\author{
Atividade física durante a pandemia de COVID-19: uma pesquisa com adultos do \\ norte do Brasil
}

\section{AUTHOR'S \\ Marcelo Marques ${ }^{1}$ (D) \\ Rodrigo Gheller ${ }^{2}$ (D) \\ Nayana Henrique ${ }^{3}$ (D) \\ Enaiane Cristina Menezes ${ }^{4}$ (D) \\ Inês Streit ${ }^{5}$ iD \\ Emerson Franchini ${ }^{1}$ (DD \\ Roseanne Autran ${ }^{6}$ (D) \\ 1 High-intensity Intermittent Exercise Physiology Research Group; Department of Sport, School of Physical Education and Sport, University of São Paulo, São Paulo, São Paulo, Brazil \\ 2 Biomechanics Laboratory, Centre of Sports (CDS), Federal University of Santa Catarina, Florianópolis, Brazil \\ 3 USP Gymnastics Research Group; Department of Sport, School of Physical Education and Sport, University of São Paulo, São Paulo, São Paulo, Brazil \\ 4 Institute of Physical Education and Sport (IEFE), Federal University of Alagoas, Maceio, Alagoas, Brazil \\ 5 Physical Activity and Health Study and Research Group: From Childhood to Aging - Health Outcomes (GEPAFS-IEDS); Faculty of Physical Education and Physiotherapy, Federal University of Amazonas, Manaus, Amazonas, Brazil \\ 6 Human Performance Laboratory (LEDEHU); Faculty of Physical Education and Physiotherapy, Federal University of Amazonas, Manaus, Amazonas, Brazil}

\section{CORRESPONDING}

\section{Marcelo Marques}

marcelomarques@usp.br

Address: School of Physical Education and Sport, University of São Paulo. 65 Prof. Mello de Moraes St, São Paulo, São Paulo, Brazil. ZIP: 05508-030.

DOI

$10.12820 /$ rbafs. $25 \mathrm{e} 0151$

\section{(cc) BY}

This work is licensed under a Creative Commons Attribution 4.0 International License.

\begin{abstract}
The aim of this study was to analyze the impact of the social distancing recommendations during COVID-19 pandemic on the physical activity behavior in adults living in the Northern Brazil region. A final sample of 654 adults (386 women) aged $33 \pm 10$ years old participated in this study. A questionnaire with 45 questions concerning sociodemographic characteristics, self-perception of health and characteristics of physical activity behavior before and after the recommendations of social distancing was applied in an online format. Comparisons between levels of physical activity before and after pandemic were conducted applying a McNemar test. A binary logistic regression was applied to analyze the factors associated to being physically active during the pandemic. Analyzing the percentage levels of physical activity before and during social distancing, we observed an increase of physically inactive behavior (19\% vs. $36.7 \%)$, as well as a decrease in active $(32.6 \%$ vs. $18.6 \%)$ and very active $(16.7 \%$ vs. $6.6 \%)$ behaviors, respectively. Among participants, $59.2 \%$ of them became sedentary during pandemic. Walking and running activities continued to be among the most practiced, although they showed a reduction during social distancing. Social distancing recommendations due to the COVID-19 pandemic caused a decrease in the overall levels of physical activity in adults living in the Amazonas State and specifically in the practice of individuals who were physically active and very physically active before pandemic.
\end{abstract}

Keywords: Social isolation; Sars-CoV2; Motor active; Cross-sectional study.

\section{RESUMO}

O objetivo deste estudo foi analisar o impacto das recomendaçôes de distanciamento social durante a pandemia COVID-19 sobre os níveis de prática de atividade física em adultos residentes na região Norte do Brasil. Uma amostra final de 654 adultos (386 mulheres) com idade de $33 \pm 10$ anos participou deste estudo. Foi aplicado, em formato online, um questionário com 45 questôes sobre características sociodemográficas, autopercepção de saúde e características do comportamento de prática de atividade física antes e após as recomendaçôes de distanciamento social. As comparaçôes entre os niveis de atividade física antes e depois da pandemia foram realizadas aplicando um teste de McNemar. Uma regressão logística binária foi aplicada para analisar os fatores associados à atividade física durante a pandemia. Analisando os níveis percentuais de atividade física antes e durante o distanciamento social, observamos um aumento do comportamento fisicamente inativo (19\% vs. 36,7\%), bem como uma diminuição dos comportamentos ativo (32,6\% vs. 18,6\%) e muito ativo (16,7\%) vs. 6,6\%). Entre os participantes, 59,2\% deles se tornaram sedentários durante a pandemia. As atividades de caminhada e corrida continuaram entre as mais praticadas, embora tenham apresentado redução durante o distanciamento social. As recomendaçôes de distanciamento social devido à pandemia COVID-19 causaram diminuição nos níveis gerais de atividade física em adultos residentes no Estado do Amazonas e especificamente na prática de individuos que eram fisicamente ativos e muito ativos antes da pandemia.

Palavras-chave: Isolamento Social; SARS-CoV-2; Atividade motora; Estudo transversal.

\section{Introduction}

The coronavirus (COVID-19) was classified as pande- mic on March 2020, due to its rapid and uncontrollable dissemination throughout the world ${ }^{1}$. Specifically, 
in Brazil, the number of infected people has increased throughout the territory ${ }^{2}$. Although São Paulo State is the center of the pandemic in Brazil, the COVID-19 has spread throughout the country and Amazonas State is one of the most affected parts of the northern region, also becoming the virus epicenter and presenting an incidence of 998.4/100.000 inhabitants and a mortality rate of 49.5/100.000 inhabitants in the region ${ }^{2}$.

The recommendation of social distancing and the fear of being infected may have impacted different aspects of health behaviors, such as regular physical activity practice ${ }^{2}$. This impact has the potential to accelerate the old well-known pandemic of physical inactivity that has been confronted for the last years ${ }^{3}$. Moreover, considering the unquestionable positive effects of a non-pharmacological intervention such as a physically active behavior on immune responses ${ }^{4,5}$, it is pivotal that during a pandemic viral infection, individuals must at least keep their usual physical activity level.

It is well established in the literature that the practice of physical activity has shown to be an effective therapy for most of the chronic diseases with direct effects on both mental and physical health ${ }^{6,7}$. Therefore, there is a strong rationale for continuing physical activity at home to stay healthy and maintain immune system function in the current conditions ${ }^{8}$. Data from Surveillance of Risk and Protective Factors for Chronic Diseases by Telephone Survey (VIGITEL-2019) ${ }^{9}$, indicated that only $39 \%$ of adults practice physical activity regularly, moreover, overweight affects $55.4 \%$ of adults in the country. Among the cities surveyed, Manaus (capital and the biggest city of Amazonas State) presented data with the highest rates of overweight (60.9\%), when compared to the other cities and the third city with the highest rate of insufficient physical activity $(49 \%)^{9}$.

Thus, it is important to extend the knowledge about the physical activity behavior during this new moment when gyms are closed and outdoor physical activity also involves some infection risk. Therefore, the aim of this study was to analyze the impact of the pandemic social distancing on the physical activity behavior in adults living in Amazonas State. We hypothesized that social distancing would lead to lower levels of physical activity.

\section{Methods}

This study sought to achieve a relevant range of adults residing in the state of Amazonas. Therefore, we considered eligible all individuals aged 18 years or more who lived in the state of Amazonas. Considering that
Manaus is the Capital and the biggest city of the State, we expected that the most part of respondents would be from Manaus. However, we adopted this procedure aiming to reach representativeness of the geographical regions of the state in the sample.

Sample size was estimated according to Raggio \& Magnanini ${ }^{10}$ considering the four million of citizens living in Amazonas State, 1.96 of confidence interval (95\%), an estimate prevalence of 0.5 and a tolerable sampling error of 0.04 , a minimum of 600 respondents were necessary. Predicting possible missing data, we aimed to achieve $10 \%$ more respondents, thus, 660 respondents. We adopted a snowball method to achieve a higher number of respondents. This method is applied when it is difficult to access subjects with the target characteristics ${ }^{17}$.

Thus, considering that the state of Amazonas has 1.559.167,889 $\mathrm{km}^{211}$, we consider this approach to be the most suitable. Data collection occurred between 01 and 30 of June 2020 (30 days collecting data). During June, several actions imposed by Amazonas government aiming to control de virus spread were still in effect in the state. During this period, only essential services as hospitals, markets and drugstores kept service to the public. However, on May-27, the state government published the strategies to reopen commerce and others activities. In this gradual planning, gyms and public parks were allowed to reopen only on June-29.

All respondents were identified by codes and they were also informed that their data would be kept confidential. Prior starting to answer the questionnaire, participants were informed concerning potential risks, benefits and study procedures, which was approved by the institution's Local Ethics Committee (CAAE: 34099320.7.0000.5020) in accordance with the Helsinki Declaration.

To measure the main outcome, we constructed a questionnaire based on specific questions that allow measuring the level of physical activity in the leisure domain only. The questionnaire comprised 45 questions and was self-administered through an online format (Google Forms) and was sent online via social media. The online questionnaire was disseminated through the researchers on social networks and messaging applications, and made available through its own link for access. When opening the link to access the questionnaire, the individual had access to the Informed Consent Form and only those who consented to participate in the research had access to the questionnaire.

The sections and items of the questionnaire were organized as follow: The first part contained questions measuring socio demographic characteristics (city where live, age, 
sex); behavioral - smoking (smoker, non-smoker); Health - Self-perception of health (excellent/good, good, fair, poor; independent variable), medication use (open-ended question. i.e. answers: antihypertensive drugs; medication for diabetes or anxiety), diagnosed diseases (open-ended question. i.e. answers: hypertension, depression) and alcohol consumption.

In the second part of the questionnaire, we aimed to obtain the main variable of interest - the physical activity behavior before and after the recommendations of social distancing in Amazonas. Thus, 13 questions were asked considering two moments, before and during the social distancing recommendations (i.e.: "Did you practice physical activity before the recommendations for social distancing"? and "Do you practice physical activity currently"? Answer options: yes or no). Individuals who reached at least 150 minutes of moderate physical activity, 75 minutes of vigorous physical activity or the equivalent combination of both intensities, were considered physically active ${ }^{12}$. Concerning exercise intensities, three questions were included to assess the behavior before social distancing and the same questions were repeated after to assess the information during social distancing [i.e.: How many days of the week did you practice physical activity of light intensity for at least 10 minutes on a continuous basis? Here it is worth remembering that light intensity activities are those that require little physical effort and that make breathing slightly stronger than normal or that lightly increase your breathing or heartbeat (for example: walking naturally, walking)]. Same question structure was repeated, however, changing the terms (light, moderate, vigorous and the activities examples).

Questions concerning customs during physical activity practice were also included, such as be accompanied by a friend/family member (answer: yes/no), be monitored by a physical education professional (answer: yes/no; if yes, presential or in virtual mode?). Specifically, for this question we included a response option "I am a physical education professional". This was important since normally, a physical education professional do not need to be accompanied by another professional. These were classified as independent variables. Be a physical education professional was also included in this category. At the end of the questionnaire, one item on the level of anxiety ("Do you consider yourself an anxious person?" Answer options: "very anxious, not very anxious, not at all anxious") were included.

To assess and categorize the physical activities practiced by respondents, we proposed an open-ended question "Do you practice physical activity for at least 10 minutes con- tinuous?" (answer: yes/no). If yes: "Which physical activity do you practice?". Despite several answers could emerge from this question, we only grouped in categories the answers that were exactly the same among participants (i.e.: strength training $=$ only respondents who reported practice with weights in a gym; running = only respondents who reported the practice run).

Data analyses were conducted on Statistical Package for Social Sciences (SPSS 22). Descriptive analyses were conducted for categorical variables (absolute and relative frequencies) and for numerical variables (position and dispersion). Comparisons between levels of physical activity, modalities and places of practice before and during social distancing recommendations were conducted applying a McNemar test. The odds ratios (95\% CI) were estimated using binary logistic regression to verify the associated factors to being physically active during social distancing recommendations. In the adjusted model, all variables that presented association with the outcome (i.e., physically active/very physically active) and socio-demographic variables (i.e., sex, age and family income) were inserted. The level of significance was set at $\mathrm{p}=0.05$.

\section{Results}

The absolute and relative frequency of socio-demographic variables and health indicators are presented in Table 1. Overall, 654 people living in 21 municipalities in the State of Amazonas accepted to answer the questionnaire and were included in analyses. Three respondents did not answer the question concerning physical activity level during social distancing recommendations. Considering that we did not have to exclude any respondent, this number achieved our a priori sample estimate. The majority of participants lived in Manaus $(85.5 \% ; n=559)$. The mean ( \pm standard deviation) age of the participants was $33 \pm 10$ years.

Among the main chronic diseases reported, anxiety disorder $(6.1 \% ; n=40)$, respiratory diseases $(6 \%$; $\mathrm{n}=39)$ and hypertension $(5.4 \% ; \mathrm{n}=35)$ were the most reported. The main drugs used were antihypertensive drugs $(5 \% ; \mathrm{n}=33)$ and anxiolytics $(3.2 \% ; \mathrm{n}$ = 21). Regarding anxiety, before the social distancing recommendation 52.9\% $(\mathrm{n}=346)$ considered themselves to be little anxious; $52.1 \%(\mathrm{n}=341)$ considered themselves to be little anxious during social distancing recommendation. Further, during social distancing recommendation, $52.6 \%(\mathrm{n}=344)$ perceived that they increased their body mass.

Regarding the time spent sitting at work/school before the COVID-19 pandemic, $28.4 \%(\mathrm{n}=186)$ re- 
Table 1 - Participants sociodemographic characteristics and health indicators.

\begin{tabular}{|c|c|c|}
\hline Variable & $\mathrm{n}$ & $\%$ \\
\hline \multicolumn{3}{|l|}{ Sex } \\
\hline Male & 268 & 41.0 \\
\hline Female & 386 & 59.0 \\
\hline \multicolumn{3}{|l|}{ Occupation } \\
\hline Unemployed & 147 & 22.5 \\
\hline Self-employed & 145 & 22.2 \\
\hline Formal Employee & 116 & 17.7 \\
\hline Public Agent & 195 & 29.8 \\
\hline Others & 51 & 7.8 \\
\hline \multicolumn{3}{|l|}{ Family Income } \\
\hline Less than 1 minimum wage & 51 & 7.8 \\
\hline From 1 to 3 minimum wage & 219 & 33.5 \\
\hline From 4 to 6 minimum wage & 178 & 27.2 \\
\hline 7 or more minimum wage & 206 & 31.5 \\
\hline \multicolumn{3}{|l|}{ Education } \\
\hline Complete elementary school/incomplete high school & 6 & 0.9 \\
\hline Complete high school/incomplete higher education & 212 & 32.4 \\
\hline Undergraduate Degree & 196 & 30.0 \\
\hline Graduated & 240 & 36.7 \\
\hline \multicolumn{3}{|l|}{ Health self-perception } \\
\hline Bad & 11 & 1.7 \\
\hline Regular & 129 & 19.7 \\
\hline Good & 367 & 56.1 \\
\hline Very good/excellent & 147 & 22.5 \\
\hline \multicolumn{3}{|l|}{ Smoking } \\
\hline No & 622 & 95.1 \\
\hline Yes & 32 & 4.9 \\
\hline \multicolumn{3}{|l|}{ Alcohol consumption } \\
\hline No & 348 & 53.2 \\
\hline Yes, less than $1 /$ week & 233 & 35.6 \\
\hline Yes, 1-3/week & 64 & 9.8 \\
\hline Yes, 4-5/week & 9 & 1.4 \\
\hline \multicolumn{3}{|l|}{ Chronic non-communicable diseases } \\
\hline No & 548 & 83.8 \\
\hline Yes & 106 & 16.2 \\
\hline \multicolumn{3}{|l|}{ Medication consumption } \\
\hline No & 498 & 76.1 \\
\hline Yes & 156 & 23.9 \\
\hline
\end{tabular}

mained seated for 6 or more hours per day and during free time $72.8 \%(n=476)$ stayed seated up to four hours per day. During social distancing period, $25.8 \%$ ( $\mathrm{n}=$ 169) remained seated for 6 or more hours per day for work/college activities and 22.9\% ( $\mathrm{n}=150)$ remained seated for 6 or more hours per day in free time (Table 2).

The levels of physical activity before and during the COVID-19 pandemic are presented in Table 2. With the social distancing recommendations, we detected an increase in the proportion of adults who were physically inactive and a decrease in the proportion of adults who were active and very active.

Regarding the physical exercise modalities, strength training ( $\mathrm{n}=213 ; 28.1 \%$ vs. $\mathrm{n}=65 ; 16.2 \%)$, running/ jogging $(\mathrm{n}=117 ; 15.5 \%$ vs. $\mathrm{n}=72 ; 17.9 \%)$ and walking $(\mathrm{n}=105 ; 13.9 \%$ vs. $\mathrm{n}=87 ; 21.6 \%)$ decreased when comparing the moments before and during COVID-19 pandemic, respectively.

Table 2 - Modalities practiced before and during social distancing recommendations.

\begin{tabular}{|c|c|c|c|c|c|}
\hline \multirow{2}{*}{ Modality } & \multicolumn{2}{|c|}{$\begin{array}{c}\text { Before social } \\
\text { distancing }\end{array}$} & \multicolumn{2}{|c|}{$\begin{array}{c}\text { During social } \\
\text { distancing }\end{array}$} & \multirow{2}{*}{$\mathrm{p}$-value } \\
\hline & $\mathrm{n}$ & $\%$ & $\mathrm{n}$ & $\%$ & \\
\hline Strength Training & 213 & 32.6 & 65 & 9.9 & $<0.001$ \\
\hline Running & 117 & 17.9 & 72 & 11.0 & $<0.001$ \\
\hline Walking & 105 & 16.1 & 87 & 13.3 & 0.130 \\
\hline Functional Training & 44 & 6.7 & 41 & 6.3 & 0.798 \\
\hline Futsal/Soccer & 41 & 6.3 & 6 & 0.9 & $<0.001$ \\
\hline Dance & 32 & 4.9 & 21 & 3.2 & 0.052 \\
\hline Others Activities & 175 & 26.8 & 99 & 15.1 & $<0.001$ \\
\hline \multicolumn{6}{|l|}{ Sitting Time } \\
\hline Work/school & & & & & $<0.001$ \\
\hline no work study & 29 & 4.4 & 43 & 6.6 & \\
\hline$<4$ hours & 247 & 37.8 & 290 & 44.3 & \\
\hline 4-6 hours & 192 & 29.4 & 152 & 23.2 & \\
\hline 6 hours or more & 186 & 28.4 & 169 & 25.8 & \\
\hline Free-time & & & & & $<0.001$ \\
\hline$<4$ hours & 476 & 72.8 & 340 & 52.0 & \\
\hline 4-6 hours & 119 & 18.2 & 164 & 25.1 & \\
\hline 6 hours or more & 59 & 9.0 & 150 & 22.9 & \\
\hline
\end{tabular}

Table 3 presents the main locations used to practice physical activity listed by respondents. Clearly gyms and public spaces appeared as the main places before distancing recommendations. During the pandemic, indoor exercise (home-based) was the main place.

Table 4 presents the descriptive analysis and the gross odds ratios $(\mathrm{OR})$ and adjusted to be active during social distancing recommendations due to the COVID-19 pandemic. We detected that practicing physical activity with a family member/friend, monitored by a physical education professional online, being a physical education professional and having good/excellent health self-perception increased the chances of being active during COVID-19 pandemic. 
Table 3 - Descriptive data of physical activity places of practice before and during social distancing recommendations.

\begin{tabular}{lccccc}
\hline \multirow{2}{*}{ Location } & \multicolumn{2}{c}{$\begin{array}{c}\text { Before } \\
\text { pandemic }\end{array}$} & \multicolumn{2}{c}{$\begin{array}{c}\text { During } \\
\text { pandemic }\end{array}$} & p-value \\
\cline { 2 - 5 } & $\mathrm{n}$ & $\%$ & $\mathrm{n}$ & $\%$ & \\
\hline Gym & 269 & 41.1 & 5 & 0.8 & $<0.001$ \\
Public spaces (street/parks/ & 155 & 23.7 & 83 & 12.7 & $<0.001$ \\
squares) & 58 & 8.9 & 266 & 40.7 & $<0.001$ \\
Home-based & 57 & 8.7 & 5 & 0.8 & $<0.001$ \\
Outdoor field & 40 & 6.1 & 2 & 0.3 & $<0.001$ \\
Clubs/Sports center/Training & & & & & \\
center & 74 & 11.3 & 28 & 4.3 & $<0.001$ \\
Others Places & & & & &
\end{tabular}

McNemar Test

\section{Discussion}

The main objective of this study was to analyze the effects of the social distancing recommendations due to the COVID-19 pandemic on the levels of physical activity behavior in adults living in Amazonas State. Our hypothesis was confirmed, since a decrease in the levels of physical activity practice was observed. During the COVID-19 pandemic, we also found an increase in physically inactive behavior and a decrease of the physically active/very physically active behavior. Nevertheless, factors as physical activity practice with a family member, friend or monitored by a physical edu- cation professional online; professional occupation and a good/excellent health self-perception were associated with physical active behavior during the social distance recommendations.

Corroborating with previous studies with other populations as Canadians ${ }^{13}$, Germans ${ }^{14}$, and other profiles as athletes ${ }^{15}$ and elderly ${ }^{16}$, the participants evaluated in this study also decreased the levels of physical activity during the COVID-19 pandemic. In a national study that aimed to analyze the factors associated with people's behavior in social isolation during the COVID-19 pandemic ${ }^{17}$, the percentage of people who were able to practice some physical activity was $40 \%$, a number compatible with the national average of $38 \%$ of people who, in a regular context, practiced some physical activity.

However, being able to is different from actually starting or continuing to practice physical activity. The fact that many people in Amazonas state are socially vulnerable, suggests they would not even consider engaging in physical activity during the COVID-19 pandemic since their thoughts were focused on meeting their essential basic needs first ${ }^{18}$. Moreover, considering that $40 \%$ of our sample reported a family income between less than one and three minimum wage (the current minimum wage in Brazil is $\mathrm{R} \$ 1,045.00$; US\$188) and Amazonas is in the lowest developed region of Brazil, it is possible

Table 4 - Descriptive analysis and factors associated with being active/very active during social distancing recommendations.

\begin{tabular}{|c|c|c|c|c|}
\hline Variables & $\begin{array}{l}\text { Sedentary } \\
\mathrm{n}(\%)\end{array}$ & $\begin{array}{l}\text { Active/very active } \\
\mathrm{n}(\%)\end{array}$ & $\begin{array}{l}\text { OR }\left(\mathrm{CI}_{95 \%}\right) \\
\text { Gross }\end{array}$ & $\begin{array}{l}\text { OR }\left(\mathrm{CI}_{95 \%}\right) \\
\text { Adjusted } ¥\end{array}$ \\
\hline \multicolumn{5}{|l|}{ Physical activity practice with Family/friend } \\
\hline No & $250(79.6)$ & $64(20.4)$ & 1 & 1 \\
\hline Yes & $110(52.9)$ & $98(47.1)$ & $3.48(2.36-5.12)$ & $2.75(1.81-4.17)$ \\
\hline \multicolumn{5}{|c|}{$\begin{array}{l}\text { Physical activity practice with a physical education } \\
\text { professional }\end{array}$} \\
\hline No & $229(77.1)$ & $68(22.9)$ & 1 & 1 \\
\hline Yes, in person & $17(53.1)$ & $15(46.9)$ & $2.97(1.41-6.26)$ & $1.94(0.87-4.36)$ \\
\hline Yes, virtual mode (online) & $44(52.4)$ & $40(47.6)$ & $3.06(1.84-5.08)$ & $2.34(1.33-4.10)$ \\
\hline I am a physical education professional & $61(60.4)$ & $40(39.6)$ & $2.21(1.36-3.58)$ & $1.83(1.07-3.10)$ \\
\hline \multicolumn{5}{|l|}{ Anxious/restless } \\
\hline No & $191(69.5)$ & $84(30.5)$ & 1 & 1 \\
\hline Yes & $296(78.7)$ & $80(21.3)$ & $0.61(0.43-0.88)$ & $0.76(0.49-1.17)$ \\
\hline \multicolumn{5}{|l|}{ Laziness /Unwilling } \\
\hline No & $229(69.8)$ & $99(30.2)$ & 1 & 1 \\
\hline Yes & $258(79.9)$ & $65(20.1)$ & $0.58(0.41-0.84)$ & $0.72(0.46-1.12)$ \\
\hline \multicolumn{5}{|l|}{ Health self-perception } \\
\hline $\mathrm{Bad} /$ regular & $128(91.4)$ & $12(8.6)$ & 1 & 1 \\
\hline Good/excellent & $359(70.3)$ & $152(29.7)$ & $4.52(2.43-8.41)$ & $3.28(1.61-6.70)$ \\
\hline
\end{tabular}

$¥=$ Adjusted for sex, income, age group and all variables in the table. 
to speculate that our findings concerning the decreased levels of physical activity during the social distancing might reflect the reality of Amazonas population.

At the time of this study, many places that promote opportunities to be physically active were temporally closed, which represented a decrement in infrastructure for people to be physically active ${ }^{18}$. We have observed that the quantity of individuals who performed physical activity in environments such as gym and health club showed a strong reduction during the social distancing. Recently, data from a national surveillance indicated that the most population living in Manaus was classified as overweight individuals ${ }^{11}$, thus we cannot assume that people would practice physical activity at home when they did not have practiced elsewhere. This may be an indication that perhaps this population is worsening their behavior in relation to physical activity and we are facing multiple pandemics that can have important interfaces and prognosis: physical inactivity, overweight/obesity and COVID-19 19 .

Despite some authors advocating in favor of indoor training, considering the feasibility, safety and effectiveness in the primary and secondary disease prevention $^{4,19,20}$, arising as an important strategy to mitigate the increase of physical inactivity behavior, our data do not support this idea. Although an increase in physical activity performed at home during social distancing, our data presented that a part of those participants who were once physically active/very active before social distancing became sedentary during the COVID-19 pandemic. In addition, there was also a decrease in the number of team sports practitioners during the period of social distancing.

Notwithstanding, a discussion has emerged in the literature. Carvalho et al. ${ }^{20}$ raised a discussion concerning the essentiality of gyms for health in the face of the COVID-19 pandemic in Brazil ${ }^{20}$. When comparing risks and benefits, the authors affirm that physical activity at home is more appropriate for this moment. Conversely, Sallis et al. ${ }^{21}$ argued that popular places for physical activity (i.e., gyms) should be retained as much as possible, as its closures may be counter-productive if the effect is decreased physical activity. Analyzing our data, more than $50 \%$ of the individuals who were physically active before social distancing practiced physical activity at privative spaces (i.e., gym's, health clubs).

Despite the fact that the most part of our sample decreased their physical active levels during social distancing, some individuals managed to stay active. Factors as the company of a family member/friend, being online monitored by a physical education professional, being a physical education professional and having good/excellent health self-perception were significantly associated to maintaining a physical active behavior during social distancing recommendations due COVID-19 pandemic.

One possible explanation may be based on behavioral psychology. According to the self-efficacy theory, individuals who feel efficacious are more likely to perform at a higher level, try new behaviors, expend more effort on those behaviors, and persevere longer when they face challenges ${ }^{22}$. Furthermore, task, barrier, and scheduling self-efficacy refer to one's confidence to participate in physical activity, overcome physical activity related barriers, and organize time and responsibilities around physical activity, respectively ${ }^{23,24}$.

In view of this, our findings suggest that individuals who were physically active before social distancing recommendations may have kept their practices focusing on being active at indoor settings (task), overcoming the challenge to readapt the exercise protocols (barriers) and keeping an agenda among others commitments (scheduling). In this sense, Jung \& Brawley $^{24}$ proposed that efficacious beliefs are one possible social-cognitive mechanism that can influence the self-regulation of goal-directed behaviors. Thus, in day-to-day circumstances, where individuals need to concurrently achieve more than one goal (i.e., increase of work at home during due the pandemic), self-regulation of exercise does not occur in isolation. Rather, exercise must be managed in conjunction with other valued activities, such as family and work. Nevertheless, the motivational presence of family/friends, the online monitoring of a physical education professional and having good/excellent health self-perception corroborates the theories already proposed in the behavioral psychology literature ${ }^{22,24}$.

Recently, Pitanga et al. ${ }^{19}$ recommended a set of exercises that may be performed at home, such as muscle strengthening (squats, push-ups, abdominal exercises, among others), stretching, balance and climbing stairs, preferably with the aid of technological procedures and online guidance of a physical education professional. Our findings corroborate this possibility, as mentioned above; this guidance with a professional was associated with a physically active behavior during COVID-19 pandemic. Finally, our sample is mostly composed by well-educated middle-aged people, which were already referred as a profile with higher interest in online 
health services and resources ${ }^{18,25}$.

Our findings allow us to endorse the message that people must be active during social distancing recommendations. We can add efforts with previous studies $^{3,5,21}$ and organized health societies from Brazil ${ }^{26}$ and other countries ${ }^{27}$ to send a message promoting focus on the maintenance of healthy performance in populations. Furthermore, during the coronavirus crisis, maintaining regular physical activity in a domestic environment is an important strategy for a healthy life, but we recognize that at the same time it is challenging, due to the restriction of space, lack of materials, self-motivation or professional orientation for a secure practice of indoor physical activity ${ }^{5}$.

This research presents some limitations. The design adopted by the study (cross-sectional) is capable to offer short-term information. Thus, future research should apply a follow-up approach to understand the physical activity behavior in a long-term social distancing scenario as at the time of this writing, several cities were still adopting the social distancing recommendations to prevent COVID-19 from spreading further. The online format that we adopted may be considered a limitation. Depending on the social strata of the individual receiving the form (i.e.: internet access, grammatical comprehension level), other more important concerns may have affected individuals when taking the time to answer the questionnaire. Therefore, it is possible that the distribution of our sample had more respondents from medium or higher socio-economic level than those in the population.

It can be concluded that the social distancing recommendations due to the COVID-19 pandemic caused decrease in the overall levels of physical activity in adults living in the Amazonas State and specifically in the practice of individuals who were physically active and very physically active before pandemic. Concomitantly, the social distancing provoked an increase of the physically inactive behavior. However, practicing physical activity with other people (family, friend, physical education professional) and having good/excellent health self-perception could lead to a better chance of being physically active during social distancing recommendations.

\section{Conflicts of interest}

The authors declare no conflict of interest.

\section{Authors Contribution}

Marques M, research concept, data collection, data analyzes, manuscript draft, critical review. Gheller R, research concept, data collection, data analyzes, manuscript draft, critical review. Henrique $\mathrm{N}$ : data collection, manuscript draft, tables and figures creation. Menezes EC, data analyzes, manuscript draft, critical review. Streit I, survey conception, critical review. Franchini E, research concept, final review, critical review. Autran R, research concept, survey conception, final review, critical review.

\section{Acknowledgments}

The authors would like to thank all the respondents that dedicate some time to respond our questionnaire.

\section{References}

1. World health Organization. Coronavirus disease (COVID-19) Pandemic 2020 [cited 2020 May 14]. Available from: https://www.who.int/

2. Ministério da Saúde. Painel Coronavírus 2020 [cited 2020 May 14]. Available from: https://covid.saude.gov.br/

3. Hall G, Laddu DR, Phillips SA, Lavie CJ, Arena R. A tale of two pandemics: How will COVID-19 and global trends in physical inactivity and sedentary behavior affect one another? Prog Cardiovasc Dis. 2020 [citado em 25 ago 2020]. Disponível em: https://www.ncbi.nlm.nih.gov/pmc/articles/ PMC7194897/

4. Luzi L, Radaelli MG. Influenza and obesity: its odd relationship and the lessons for COVID-19 pandemic. Acta Diabetol. 2020,57(6):759- 64

5. Rodríguez M, Crespo I, Olmedillas H. Exercising in times of COVID-19: what do experts recommend doing within four walls? Rev Esp Cardiol. 2020; 73(7):527-29

6. Lavie CJ, Ozemek C, Carbone S, Katzmarzyk PT, Blair SN. Sedentary Behavior, Exercise, and Cardiovascular Health. Circulation. 2019;124(5):799-815.

7. Ozemek C, Laddu DR, Lavie CJ, Claeys H, Kaminsky LA, Ross R, et al. An Update on the Role of Cardiorespiratory Fitness, Structured Exercise and Lifestyle Physical Activity in Preventing Cardiovascular Disease and Health Risk. Prog Cardiovasc Dis. 2018;61(5-6):484-90.

8. Chen PJ, Mao LJ, Nassis GP, Harmer P, Ainsworth BE, Li F. Coronavirus disease (COVID-19): The need to maintain regular physical activity while taking precautions. J Sport Health Sci. 2020;9(2):103-4.

9. Vigitel Brazil. Surveillance of risk and protective factors for chronic diseases by telephone survey: estimates of frequency and sociodemographic distribution of risk and protective factors for chronic diseases in the capitals of the 26 Brazilian states and the Federal District in 2019.

10. Raggio LR, Magnanini MF. A lógica da determinaçäo do tamanho da amostra em investigaçöes epidemiológicas. Cad Saúde Colet 2000;8:9-28.

11. Instituto Brasileiro de Geografia e Estatística. 2020 [cited 2020 May 29]. Available from: https://cidades.ibge.gov.br/ brasil/am/panorama.

12. Garber CE, Blissmer B, Deschenes MR, Franklin BA, Lamonte MJ, Lee I, et al. American College of Sports Medicine position stand. Quantity and quality of exercise for developing and maintaining cardiorespiratory, musculoskeletal, and neuromotor fitness in apparently healthy adults: guidance for prescribing exercise. Med Sci Sports Exer. 2011;43(7):1334-59. 
13. Lesser IA, Nienhuis CP. The Impact of COVID-19 on Physical Activity Behavior and Well-Being of Canadians. I J Environ Res Public Health. 2020;17(11):3899

14. Mutz M, Gerke M. Sport and exercise in times of selfquarantine: How Germans changed their behaviour at the beginning of the Covid-19 pandemic. Int Rev Sociol Sport. 2020 [citado em 27 ago 2020]. Disponível em: https:// journals.sagepub.com/doi/pdf/10.1177/1012690220934335

15. Pillay L, van Rensburg DCCJ, van Rensburg AJ, Ramagole DA, Holtzhausen L, Dijkstra HP, et al. Nowhere to hide: The significant impact of coronavirus disease 2019 (COVID-19) measures on elite and semi-elite South African athletes. J Sci Med Sport. 2020;23(7):670-9.

16. Yamada M, Kimura Y, Ishiyama D, Otobe Y, Suzuki M, Koyama S, et al. Effect of the COVID-19 Epidemic on Physical Activity in Community-Dwelling Older Adults in Japan: A Cross-Sectional Online Survey. J Nutr Health Aging. 2020;23:1-3.

17. Bezerra ACV, Silva CEM, Soares FRG, Silva JAM. Factors associated with people's behavior in social isolation during the COVID-19 pandemic. Cienc Saúde Colet. 2020;25(Suppl1):2411-21.

18. Matias TS, Dominski FH. The COVID-19 pandemic challenges physical activity with two emerging paradigms. Rev Bras Ativ Fís Saúde. 2020;25:1-6.

19. Pitanga FJG, Beck CC, Pitanga CPS. Inatividade física, obesidade e COVID-19: perspectivas entre múltiplas pandemias. Rev Bras Ativ Fís Saúde. 2020;25:1-4.

20. Carvalho FFB, Silva RG, Oliveira RB. A essencialidade das academias de ginástica para a saúde diante da pandemia da COVID-19 no Brasil. Rev Bras Ativ Fís Saúde. 2020;25:1-5.
21. Sallis JF, Pratt M, Sallis JF. Multiple benefits of physical activity during the Coronavirus pandemic. Rev Bras Ativ Fís Saúde. 2020;25:1-5.

22. Bandura A. Self-efficacy: The exercise of control. New York: Freedom and Company; 1997.

23. Sweet SN, Fortier MS, Strachan SM, Blanchard CM. Testing and Integrating Self-Determination Theory and Self-Efficacy Theory in a Physical Activity Context. Can Psychology. 2012;53(4):319-27.

24. Jung ME, Brawley LR. Concurrent management of exercise with other valued life goals: Comparison of frequent and less frequent exercisers. Psychol Sport Exe. 2010;(11):372-7.

25. Andreassen HK, Bujnowska-Fedak MM, Chronaki CE, Dumitru RC, Pudule I, Santana S et al. European citizens' use of E-health services: A study of seven countries. BMC public health. 2007;7(53):1-7.

26. Sociedade Brasileira de Medicina do Esporte. 2020 [cited 2020 July 23]. Available from: http://www.medicinadoesporte.org. br/wp-content/uploads/2020/07/nota-3-sbmee.pdf.

27. American College of Sports Medicine. 2020 [cited 2020 July 23]. Available from: https://www.acsm.org/read-research/ newsroom/news-releases/news-detail/2020/03/16/stayingphysically-active-during-covid-19-pandemic.

Received: $30 / 08 / 2020$

Approved: 20/10/2020

\section{Quote this article as:}

Marques M, Gheller R, Henrique N, Menezes EC, Streit I, Franchini E, Autran R. Physical activity during the COVID-19 pandemic: a survey with adults in Northern Brazil. Rev Bras Ativ Fís Saúde. 2020;25:e0151. DOI: 10.12820/rbafs.25e0151 